\title{
Modelling seasonal circulation and thermohaline structure of the Caspian Sea
}

\author{
M. Gunduz ${ }^{1}$ and E. Özsoy ${ }^{2}$ \\ ${ }^{1}$ Institute of Marine Sciences and Technology, Dokuz Eylul University, Izmir, Turkey \\ ${ }^{2}$ Institute of Marine Sciences, Middle East Technical University, Erdemli, Turkey \\ Correspondence to: M. Gunduz (murat.gunduz@deu.edu.tr)
}

Received: 6 January 2014 - Published in Ocean Sci. Discuss.: 22 January 2014

Revised: 9 April 2014 - Accepted: 28 April 2014 - Published: 10 June 2014

\begin{abstract}
The wind- and buoyancy-driven seasonal circulation of the Caspian Sea is investigated for a better understanding of its basin-wide and mesoscale dynamics, mixing and transport. The model successfully reproduces the following basic elements of the circulation: the southward-flowing current systems along the eastern and western coasts, the upwelling along the eastern coast, the cyclonic circulation in the Middle Caspian Sea (MCS), especially in winter, and the cyclonic and anticyclonic cells of circulation in the South Caspian Sea (SCS). The observed seasonal variability of sea level and sea surface temperature (SST) is well reproduced. Mesoscale structures, not always evident from hydrographic observations, are identified.
\end{abstract}

\section{Introduction}

The Caspian Sea $\left(36^{\circ}\right.$ to $47^{\circ} \mathrm{N}$ and $46^{\circ}$ to $\left.54^{\circ} \mathrm{E}\right)$ is a totally enclosed, landlocked body of water on the Euro-Asian continent. It is a fertile inland sea located between vast deserts of Central Asia, extensive northern plains and the Caucasian high mountain range. Large uncertainties exist with respect to climate change in this zone of sharp transition between climates of the neighbouring Euro-Mediterranean, Siberian, Indian Ocean and Central Asian domains (Bengtsson, 1998; Arpe and Roeckner, 1999; Arpe et al., 2000; Özsoy, 1999; Özsoy et al., 2001). Updated information on the environmental status of the sea can be found at http://www. caspianenvironment.org.

Large variations in sea level, often of abrupt nature, are well documented in hydrological and sedimentary records. Consequent flooding of the adjacent flat land in the past has had detrimental effects on neighbouring societies, for instance on the ancient Khazar state that once occupied its northern shores (Rodionov, 1994). Despite its overwhelming importance, sea level has consistently defied prediction, because of a poor understanding of the water cycle in the extensive catchment basin and, more generally, the specific response of the region to climate. Yet sea level change is often a cumulative indicator of a series of other changes leading up to possible regime shifts between alternative states of the ecosystem. Large variations have been observed in winter mixing, varying from shallow to deep convection, with strong cases of deep ventilation (Kosarev and Yablonskaya, 1994; Dumont, 1998). In one such case, following the abrupt drop of sea level in 1977, dramatic changes in stratification and nutrient regimes are known to have occurred (Kosarev and Yablonskaya, 1994).

Like the neighbouring Black Sea, the Caspian Sea is an enclosed basin with large fresh-water inputs from rivers, the most significant such contribution being from the Volga, with others including the Ural, Kura and Terek. Input from rivers are known to be capable of creating buoyancy-driven shelf currents, as shown by a number of detailed studies (e.g. Kourafalou et al., 1996; Lazure and Jegou, 1998; Chen et al., 1999).

It is challenging to capture and to explain the observed complex features of the Caspian Sea circulation arising from wind and atmospheric/riverine buoyancy forcing acting on this elongated, enclosed sea and worthwhile to study the rather large contrasts between its basins, the variability of flow and mixing processes along its coasts.

The general circulation inferred from hydrographic survey data from the end of the 19th century till the 1950s has 
been described as being cyclonic in the Middle Caspian Sea (MCS). Instrumental surveys along the western coast of the MCS, carried out in 1935-1937 (Stockman, 1938; Baidin and Kosarev, 1986), have shown predominantly southward currents along the western coast of the basin. Data from oceanographic observations since the 1950s in coastal areas have confirmed southward currents along the western coast of the MCS (Klevtsova, 1967) and a semi-permanent anticyclonic vortex south of the Abşeron peninsula (Tsytsarev, 1967). Southward surface currents along the eastern coast of the MCS (Klevtsova, 1967; Bondarenko, 1993) evident in these observations at first seem to contradict the abovementioned general cyclonic circulation of the MCS. However, below the surface circulation, northward currents with seasonal variation are known to exist along the eastern coast of the basin, supporting the proposed cyclonic circulation (Kosarev and Yablonskaya, 1994). A southward current east of the Abşeron Peninsula passing to the South Caspian Sea (SCS) has been inferred from hydrographic observations, with a current speed of $50-60 \mathrm{~cm} \mathrm{~s}^{-1}$ at the surface, decreasing to $40-50 \mathrm{~cm} \mathrm{~s}^{-1}$ near the bottom (Kosarev and Yablonskaya, 1994). By making use of satellite-derived SST and chlorophyll data, Sur et al. (2000) have revealed the southward flow of cold water from the north along the west coast, and the northward intrusion of warm water from the SCS to the MCS near the eastern coast. In the shallow North Caspian Sea (NCS), the circulation appears to be almost totally controlled by local winds (Bondarenko, 1993; Terziev et al., 1992). Based on the above-mentioned features, Lednev (1943) has created the schematic representation of the Caspian Sea circulation shown in Fig. 1.

The construction of the missing elements of the above description of seasonal circulation could hopefully be achieved through details supplied by numerical model studies performed from the mid-1970s until the present. The diagnostic model developed by Sarkisyan et al. (1976) indicated a mainly wind-driven circulation and the effects of thermal stratification on the establishment of this circulation. Diagnostic models of Trukhchev et al. (1995) and Tuzhilkin et al. (1997) have indicated dipole structures, consisting of a cyclonic and anticyclonic pair in the northwest and southeast, respectively, of the MCS, and an anticyclonic and cyclonic pair in the northwest and southeast, respectively, of the SCS basins.

Later, a review and a series of computations of the seasonal circulation based on a coupled sea hydrodynamics, air-sea interaction and sea ice thermodynamics model of the Caspian Sea was made by Ibrayev et al. (2010) establishing the importance of seasonal changes from cyclonic to anticyclonic circulation patterns, topographic generation and steering of currents along the eastern and western coasts. A persistent northward transport by subsurface currents was shown along the eastern shelf slope, despite the surface currents often being directed southward in the same region, confirming the features reviewed above, as well as displaying horizontally

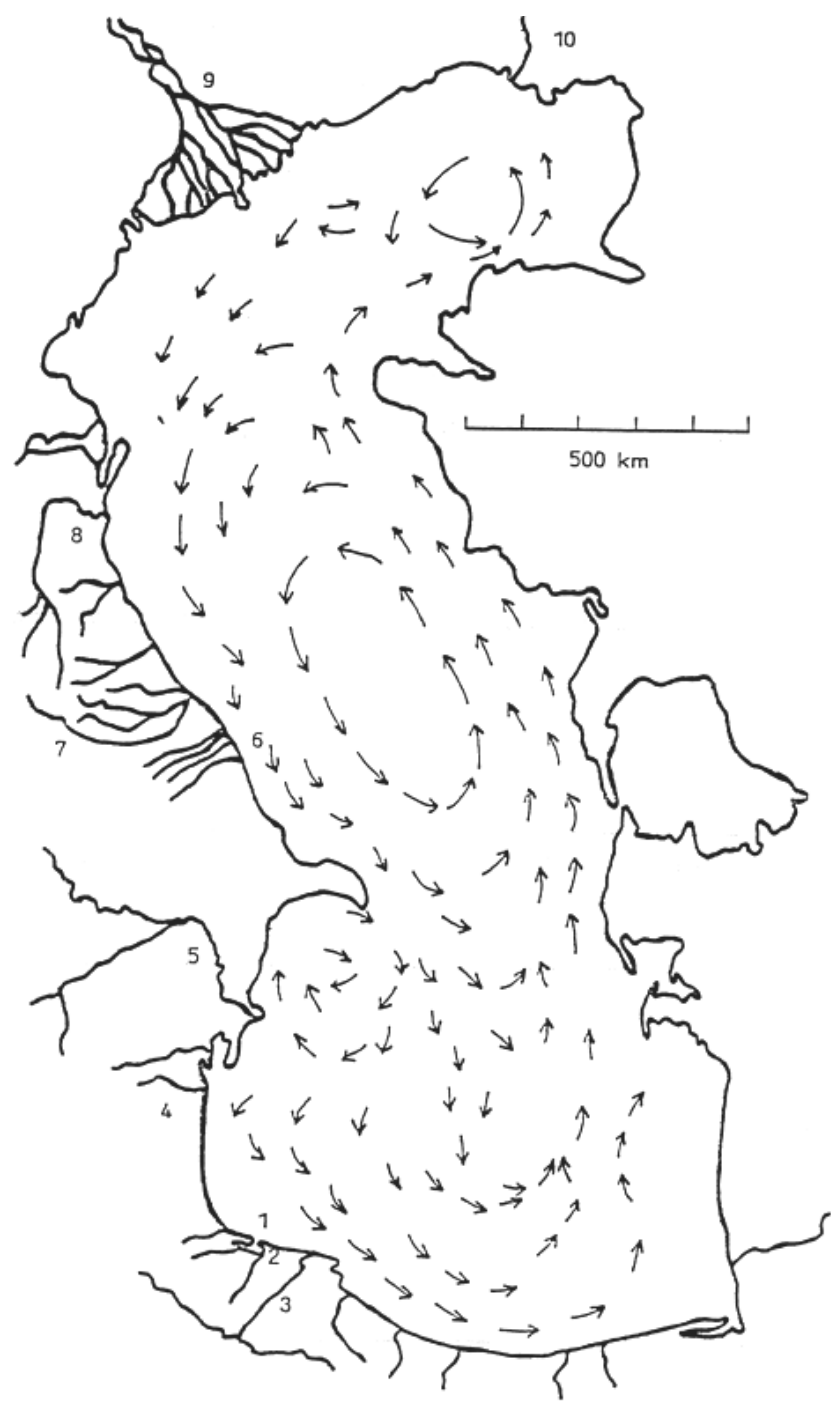

Figure 1. Schematic representation of the Caspian Sea currents (Lednev, 1943).

and vertically layered structures of the boundary currents over a mild slope. Recently, by assimilating climatological temperature and salinity into a primitive-equation ocean circulation model, Knysh et al. (2008) obtained a cyclonic circulation in the MCS in winter, with the above-mentioned features of a southward surface current and a northward subsurface current along the eastern shelf. Knysh et al. (2008) found a highly variable circulation corresponding to an intense, mostly barotropic circulation in February and a relatively less intense baroclinic circulation in the March-June period.

Faced with an insufficient understanding of the circulation with its various details hidden from current knowledge, our primary focus is to recreate the 3-D seasonal circulation under climatological wind, surface and river buoyancy forcing to discover basin-wide features and mesoscale details and check their consistency with available observations. 


\section{Bathymetry}

Each of the three basins of the Caspian Sea has distinct physical and biological properties (Fig. 2). The NCS is extremely shallow, with an average depth of about $5 \mathrm{~m}$, the Ural Furrow of $8-10 \mathrm{~m}$ depth cutting through the otherwise flat region. The NCS is separated from the MCS by an abrupt depth transition at the shelf edge. The depth in the MCS is about $190 \mathrm{~m}$ on average, reaching a maximum value of $788 \mathrm{~m}$ at the Derbent depression on its western side. The western slope of the MCS is quite steep, whereas the eastern slope is milder. The Garabogazköl, a small enclosure with less than $10 \mathrm{~m}$ depth, originally connected to the Caspian Sea and adjacent to the eastern deserts, was recently been dammed to reduce water loss from the Caspian Sea by evaporation. The deep basins of the MCS and the SCS are separated by the Abşeron sill of $150 \mathrm{~m}$ maximum depth. The SCS is the deepest basin, with a maximum depth of $1025 \mathrm{~m}$ and shallower depressions of 900 to $1000 \mathrm{~m}$ depth. The wide continental shelf extending along the eastern side of the SCS is connected to the narrow shelf continuing along the eastern side of the MCS.

\section{Model features and setup}

Features of the Caspian Sea, such as the weak stratification, deep mixing and strong topographic gradients at continental slopes and sills make the HYbrid Coordinate Ocean Model (HYCOM) (Bleck, 2006) ideally suited for our studies.

The HYCOM, a generalized (hybrid, isopycnal/terrainfollowing $\sigma / z$ level) coordinate primitive-equation model, has been widely used for global and regional studies and tested for performance. To cite a few recent studies, the choices of vertical coordinates have been evaluated with regard to the Atlantic Ocean by Chassignet et al. (2003); performance in the Kuroshio Extension region has been tested by Kelly et al. (2007); and the sensitivity to atmospheric forcing in the Black Sea has been investigated by Kara et al. (2005).

The hybrid coordinates extend the range of applicability of the model so as to allow better representation of shallow coastal or weakly stratified waters. The transition from isopycnal coordinates in stratified water to fixed-depth $z$ levels in unstratified surface mixed layer and to terrain-following $\sigma$ levels in shallow water occurs smoothly by making use of a layer continuity equation (Bleck, 2002).

A Mercator grid $(204 \times 354)$ with meridional resolution of $4.4 \mathrm{~km}$ and zonal resolution of $0.04 \times \cos$ (lat) $\times 111.2 \mathrm{~km}$ corresponding to $3.0-3.3 \mathrm{~km}$ is used. HYCOM is capable of migrating between isopycnal, $z$ level and $\sigma$ level. In this study, the combination of only $z$ level and $\sigma$ level are used. Thirty hybrid layers consisting of 14 sigma levels to a depth of $50 \mathrm{~m}$ and $16 z$ levels below that depth are used in the vertical.
Table 1. Climatological mean flow values obtained from RivDIS (see online at http://daac.ornl.gov/RIVDIS/rivdis.shtml) for the river discharge into the Caspian Sea.

\begin{tabular}{lrrr}
\hline & Volga $\left(\mathrm{m}^{3} \mathrm{~s}^{-1}\right)$ & Kura $\left(\mathrm{m}^{3} \mathrm{~s}^{-1}\right)$ & $\mathrm{Ural}_{\left(\mathrm{m}^{3} \mathrm{~s}^{-1}\right)}$ \\
\hline Jan & 3917.5 & 467.9 & 60.9 \\
Feb & 3960.2 & 493.9 & 56.0 \\
Mar & 4032.8 & 553.0 & 70.1 \\
Apr & 7488.5 & 813.3 & 899.5 \\
May & 24021.5 & 1067.2 & 1377.3 \\
Jun & 20075.3 & 850.8 & 409.7 \\
Jul & 8163.6 & 451.7 & 198.5 \\
Aug & 5590.6 & 313.7 & 131.9 \\
Sep & 5036.9 & 326.7 & 105.3 \\
Oct & 5358.7 & 387.9 & 98.4 \\
Nov & 5450.0 & 423.8 & 90.8 \\
Dec & 3948.0 & 461.0 & 63.4 \\
\hline
\end{tabular}

River runoff is first added to a single ocean grid point and smoothed over surrounding ocean grid points, treated as a contribution to precipitation. Monthly discharges of the Volga River, which account for about $80 \%$ of the climatological mean river discharge of $250 \mathrm{~km}^{3} \mathrm{yr}^{-1}$ (Kosarev and Yablonskaya, 1994), and the two other major rivers Ural and Kura, are applied, based on the Global River Discharge (RivDIS) climatology (Vorosmarty et al., 1997). Table 1 shows the monthly discharge of the rivers from RivDIS data set. The peak discharges of these rivers typically occur in April-July, decreasing during November-December. Exchange with Garabogazköl, currently almost entirely disconnected from the Caspian Sea, has not been taken into consideration.

The gridded temperature and salinity climatological data $\left(0.25^{\circ} \times 0.2^{\circ}\right.$ resolution and $0,5,10,15,20,25,30,50$, $75,100,125,150,200,250,300,400,500,600$ and $800 \mathrm{~m}$ depth levels) of Ibrayev et al. (2001) are used to initialize the model, after interpolation to the model grid.

The atmospheric forcing is based on the seasonal average ECMWF Re-Analysis (ERA-40) (resolution $1.125^{\circ} \times$ $1.125^{\circ}$ ) of the European Centre for Medium-Range Weather Forecasts (ECMWF), encompassing 40 years of data (1958-1998). The surface forcing climatology is constructed for the following variables; zonal and meridional components of wind stress, wind speed at $10 \mathrm{~m}$ above the sea surface, air temperature, air mixing ratio at $2 \mathrm{~m}$ above the sea surface, precipitation, net shortwave radiation and net longwave radiation. The high frequency (6-hourly) component has then been added to the wind stress in the same way as described by Wallcraft et al. (2003), choosing data from the September 1994-September 1995 period as a typical year that would most closely match annual cyclicity in winds.

The model is initialized with monthly mean temperature and salinity climatology and forced with climatological mean seasonal wind stress and surface heat fluxes, with surface 
(a) 27 August 2004

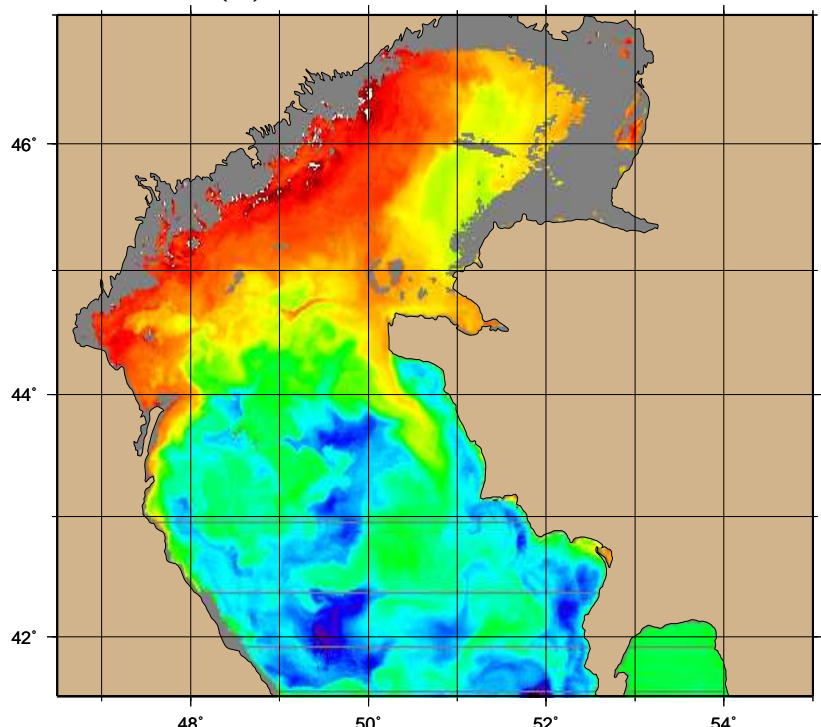

(b) 30 Ángust 2004

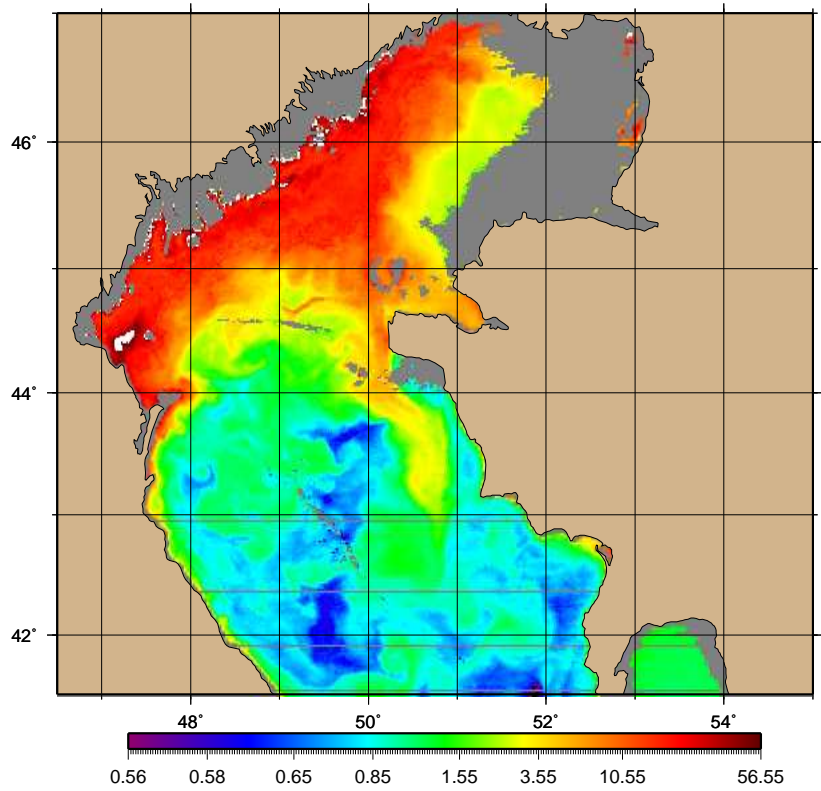

Figure 2. The Caspian Sea model bathymetry.

salinity relaxed to the observed seasonal mean values. A run period of about eight model years was sufficient to reach statistical equilibrium (i.e. a perpetual annual cycle, with negligible temporal drift). The model results presented in the following sections are based on either daily or monthly means that were constructed from the last four years of the simulations.

\section{Seasonal circulation}

Figure 3 (upper) shows the annual mean circulation of the Caspian Sea averaged over 0-30, 30-150 and 150-300 m
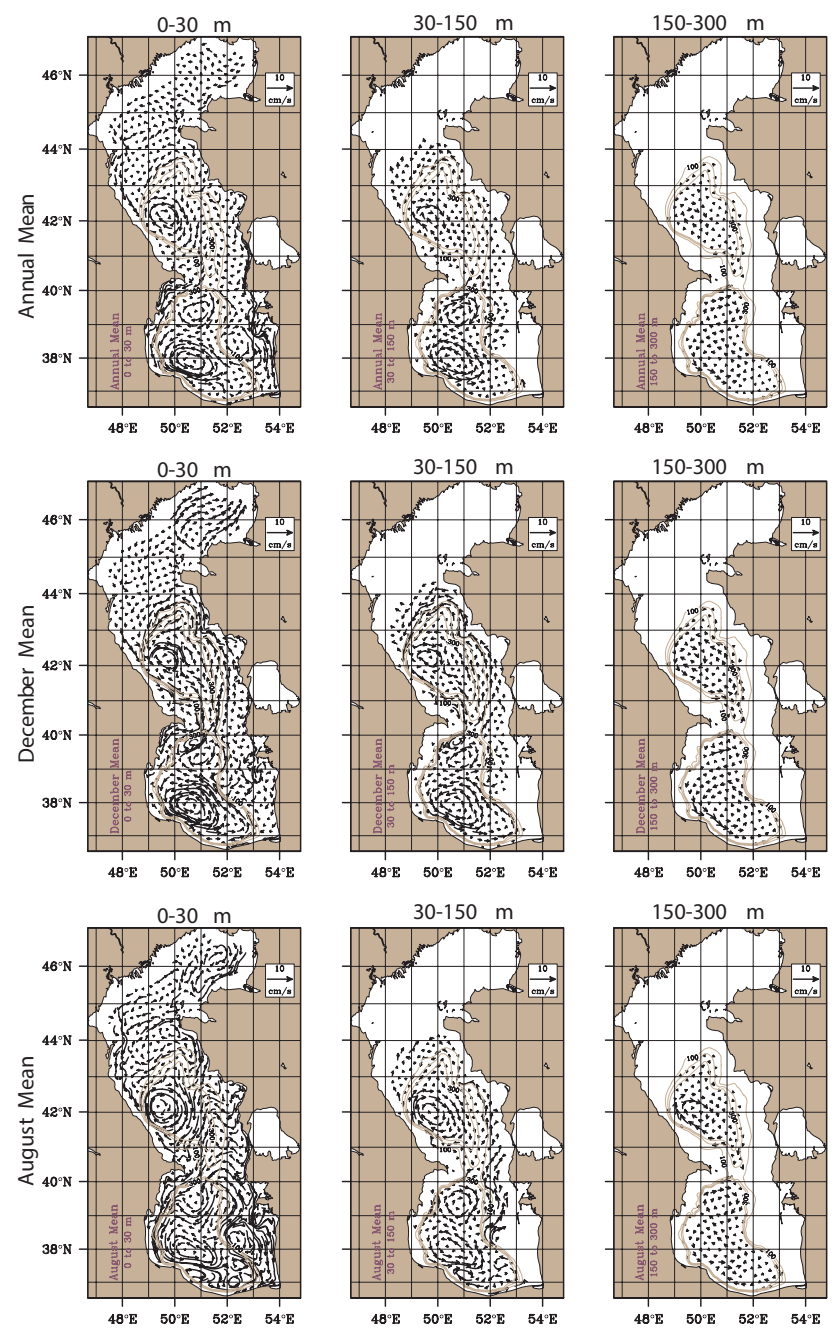

$150-300 \mathrm{~m}$

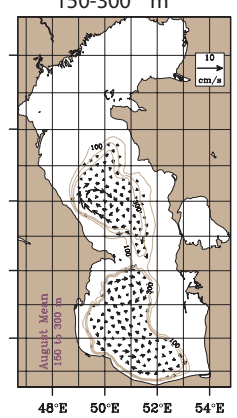

Figure 3. Model-derived mean currents $\left(\mathrm{cm} \mathrm{s}^{-1}\right)$ from a control run averaged over depth intervals of $0-30 \mathrm{~m}, 30-150 \mathrm{~m}$ and $150-300 \mathrm{~m}$. Contour lines shows the 100, 200 and $300 \mathrm{~m}$ bathymetry contours. Upper row: annual; middle row: December; lower row: August.

depth intervals. Annual mean currents are generally found to be weak, with maximum values of $7-8 \mathrm{~cm} \mathrm{~s}^{-1}$ along coastal areas. Although surface currents driven by daily winds display significant variability, this is not reflected in the annual average circulation.

The circulation in the shallow Northern Caspian Sea is especially sensitive to wind direction and speed. Because there are no stable current patterns observed here, the magnitude of the annual mean current is low. The annual mean indicates northward flow in general, with considerable variation from one season to another.

Although the current model has an ice model incorporated into it, the amount of ice predicted by the model was usually less than the observed levels (not shown). The inefficiency of ice formation in the model could possibly be attributed to insufficient heat loss from the shallow northern Caspian Sea 


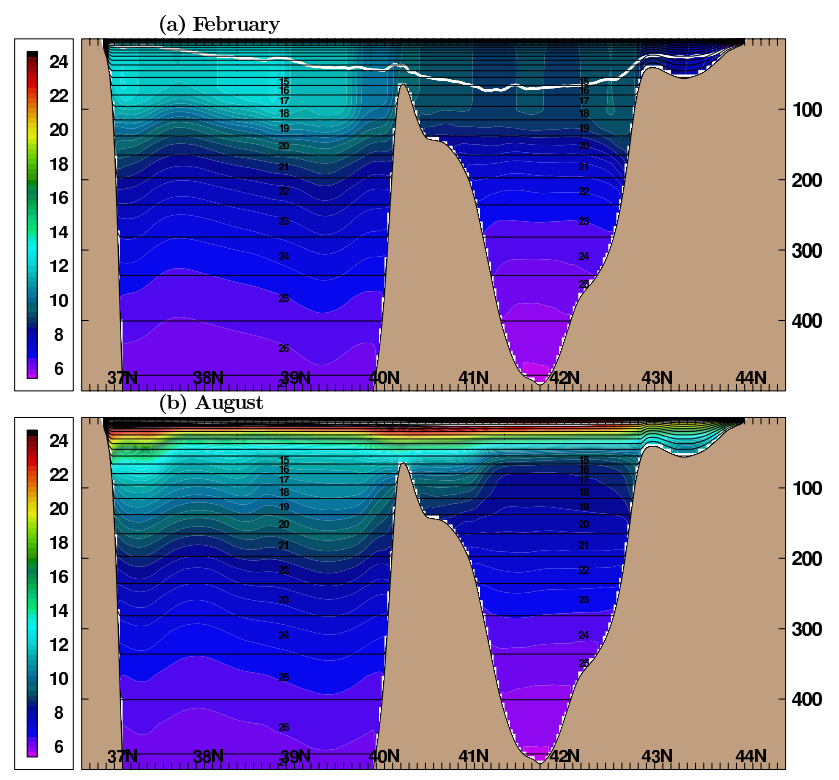

Figure 4. Model-derived monthly mean temperature at $50^{\circ} \mathrm{E}$ ((a) February (b) August).

estimated by the model bulk formulae. Firstly, the heat fluxes were obtained from a coarse-resolution atmospheric model used by the ECMWF reanalysis. Secondly, careful evaluations of heat flux estimates compared with the observations (Pettenuzzo et al., 2010) have shown that the ERA-40 reanalysis data set used in our study is unable to close the surface budgets of heat in the case of the Mediterranean Sea unless some corrections are applied. Because we did not apply such corrections, which must be carefully computed for the Caspian Sea, we had to accept the fluxes given by the existing module of HYCOM, although we note that the ice effects are underrepresented in winter months in the NCS as is the case in December (Fig. 3 middle)

The most striking feature of the Caspian Sea circulation is the presence of an anticyclonic gyre to the west of the MCS at about $42^{\circ} \mathrm{N}$ and the cyclonic and anticyclonic pair of gyres in the SCS, respectively at $38^{\circ} \mathrm{N}$ and $39.5^{\circ} \mathrm{N}$. The intensive anticyclonic gyre in the Derbent depression of the MCS and the two circulation cells located in topographic depressions of the SCS are mostly barotropic, with well-preserved features from the surface to the bottom. All three cells are persistent throughout the year with increasing intensity in summer, consistent with the seasonal winds.

The southward surface currents reproduced by the model along either side of the Caspian Sea are in good agreement with the available observations reviewed above. The southward current seems to be confined to shallow water (depth $<$ $20 \mathrm{~m}$ ) along both coasts. The intensity of the current along the western coast decreases south of $42^{\circ} \mathrm{N}$, as part of the current becomes incorporated into the anticyclonic gyre there and, after recirculating around it, the current enters the SCS

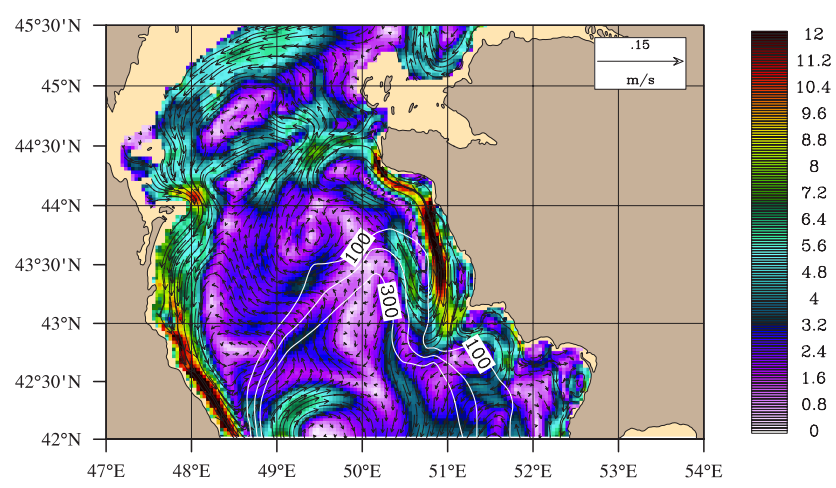

Figure 5. Model-derived current over the MCS in in July. The southward flow along the northeastern coast of the MCS is evident in this figure.

on the western side of the Abşeron sill. The southward surface current along the eastern coast of the MCS changes direction below the surface layer to become a northward current at depth, a well-known feature from observations and earlier model results. This current immediately below the surface layer supports the existence of a basin-wide subsurface cyclonic circulation following the coasts of the MCS. The persistent feature identified as the Derbent anticyclone in the western part of the basin is integrated within and interacts with the described cyclonic cell.

Throughout the year, southward flow is evident throughout the water column at the western side of the Abşeron sill offshore of the Abşeron Peninsula, in agreement with observations (Kosarev and Yablonskaya, 1994). In contrast to the southward current on its western side, a northward current occurs on the eastern side of the sill, transporting warm water of the southern basin to the north. This northward current is evident from satellite SST data, often as a vein of warm water originating from the SCS and flowing towards the MCS along the eastern coast. The sill topography appears to be an important factor controlling the exchange between the two basins; the exchange in turn responds to the structure of the seasonal circulation in the adjacent basins.

In the South Caspian Sea, a persistent dipole pattern and a basin-wide cyclonic circulation confined to the $100-300 \mathrm{~m}$ bathymetric contours are observed. The cyclonic shallow circulation encircles the inner basin dipole pattern. With regard to the dipole structure, the cyclonic cell is located in the southwestern part of the basin, while the anticyclonic cell is located to its north. The anticyclonic cell, identified as the "Kura anticyclone" by Trukhchev et al. (1995) and Tuzhilkin et al. (1997), was first described by Lednev (1943). These authors also found the cyclonic cell in the southeastern part of the SCS. The dipole pattern is a permanent feature of the SCS, evident during the whole year, with a mainly barotropic structure extending from the surface to the bottom. The southward current originating from the MCS passes the sill offshore of the Abşeron Peninsula, progressing in the 


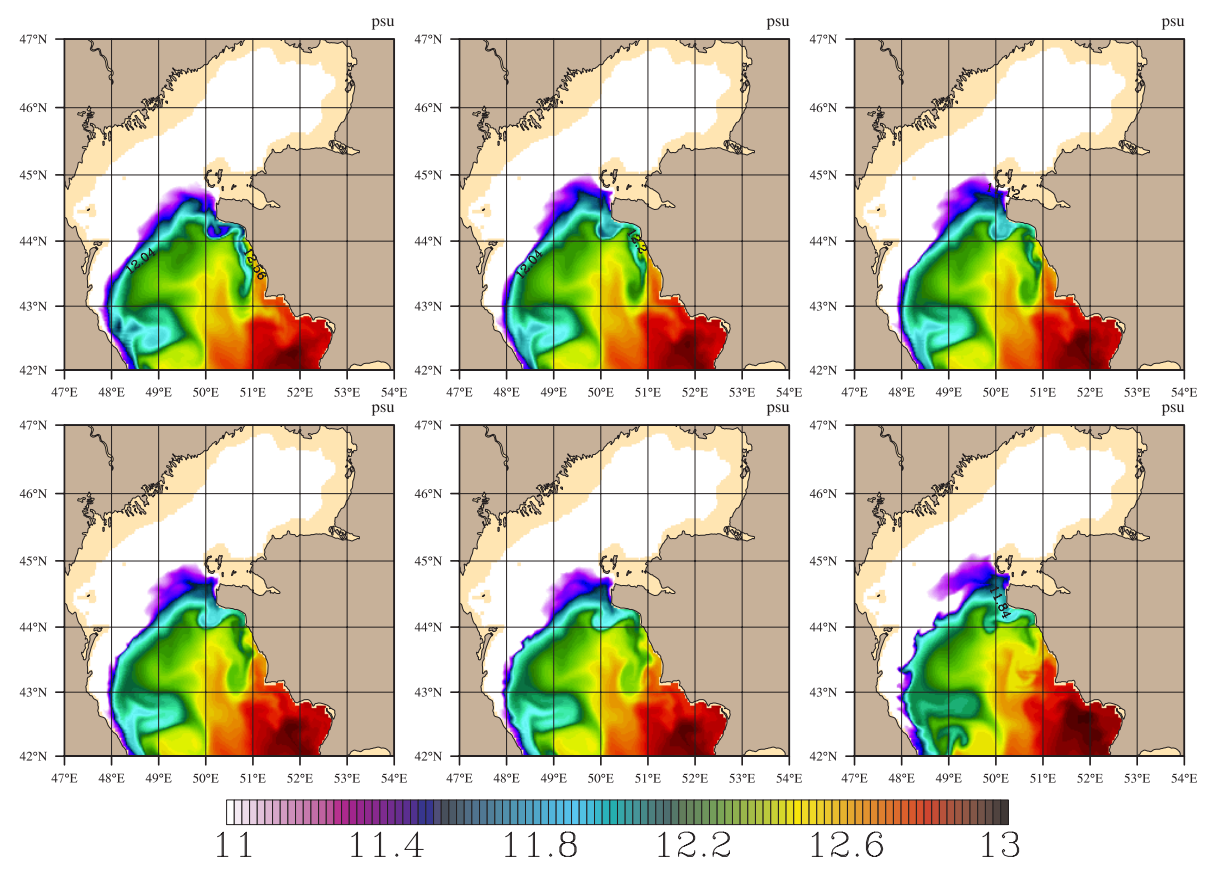

Figure 6. Sea surface salinity (SSS) in practical salinity unit (psu) for 28/30/31 July (upper panel) and 1/2/8 August (lower panel).

form of a coastal jet along the western coast of the SCS. This coastal current reaches its maximum intensity after becoming confined to the steep inner shelf along the west coast of the SCS. The coastal jet follows the shallow bathymetry to turn clockwise around the SCS along the 100-300 m bathymetric contours of the continental slope, finally arriving at the eastern side of the Abşeron sill. Outside this cyclonic circulation cell, southerly flow occurs on the wide eastern continental shelf of the SCS. The double gyre SCS seasonal circulation appears more stable compared to the circulation patterns in the other two basins of the Caspian Sea, in confirmation of Peeters et al. (2000), who showed enhanced vertical stability of this basin, based on the Brunt-Väisälä frequency.

December and August monthly mean currents averaged over depth intervals of $0-30 \mathrm{~m}, 30-150 \mathrm{~m}$ and $150-300 \mathrm{~m}$, are plotted in the middle and lower panels of Fig. 3, respectively, to represent winter and summer regimes of circulation. A cyclonic surface circulation dominates the Caspian Sea from December to March, when the wind blows mainly from the east and northeast directions. Weak currents are found in most of the MCS, except within the coastal jets and the midbasin anticyclonic cell. The three-cell circulation preserves its structure in winter.

In summer, westward Ekman surface currents across the MCS and upwelling along the eastern coast are driven by strong north to northwesterly prevailing winds. Concurrent with the summer surface circulation, a northward-flowing intermediate depth countercurrent exists along the eastern coast of the MCS. The Derbent anticyclone on the western side of the basin strengthens in summer. This anticyclone has similarly been predicted by Schrum et al. (unpublished data) using the HAMburg Shelf-Ocean-Model(HAMSOM) forced by surface buoyancy and momentum fluxes computed from six hourly ECMWF ERA-15 atmospheric reanalysis data set. The southward advection of fresh water from the Volga river by the southward-flowing coastal jet and the downwelling created at the west coast by the Ekman currents create favourable conditions for the intensification of the Derbent anticyclone in summer. There are two dominant wind regimes in the Caspian Sea. During the winter, wind blows to the west, and in summer the wind direction changes dramatically and the wind starts to blow to the south. Gunduz (2014) has shown that variation of the wind speed and direction (Fig. 5 in the paper) may have an influence on the changing of the cyclonic circulation in winter to the anticyclonic one in summer in the MCS.

From October to January, the northward current flowing along the SCS and the MCS turns west upon reaching the northern continental slope. Then, following the western coast with increased velocity, it completes a basin-wide cyclonic circuit. The northward flow along the eastern coast transports warm water originating from the SCS into the MCS in autumn and winter months. In summer, this flow appears diminished because of the strong Ekman circulation that creates upwelling along the eastern coast. The Derbent anticyclone is weaker in winter and almost diminished in April but rejuvenates in June.

It is evident from the above description that the Caspian Sea general circulation is dominated by a basin-scale cyclonic "rim current" following its narrow coastal topography 
and continental slopes wherever these slopes are sharply defined as well as cyclonic/anticyclonic gyres present within this circulation system in the deep basins of the MCS and SCS. The topography of the basins and the Abşeron sill play important roles in steering this circulation. Coastal jet flows arise especially along the slopes of the western coast, only to be interrupted by the sharp protrusion of the Abşeron Peninsula. The circulation along the wider continental shelves and continental slopes of the corrugated eastern coast (see Fig. 2) is more complex, showing a reversal of direction in the vertical and a complicated horizontal structure. The general circulation appears to be mainly wind driven, while sources of buoyancy also play significant roles.

The most challenging task for the modelling of enclosed seas like the Caspian Sea is to properly represent the annual thermal cycle, since the thermal regime changes from an entirely thermally mixed one in winter to a strongly stratified one in summer (see Beletsky and Schwab (2001), who detected the same sequence in the case of Lake Michigan). Our simulations with the HYCOM Caspian Sea model were able to reproduce the following main features of the Caspian Sea thermal structure.

Figure 4 shows the temperature cross sections along $50^{\circ} \mathrm{E}$ in February and August. In this figure, the white line shows the base of the mixed layer. In February, there are considerable differences in mixed layer depth (MLD) between the two deep basins of the Caspian Sea. While the MLD in MCS is about $100 \mathrm{~m}$ in winter, it only reaches to $20 \mathrm{~m}$ in the SCS. The most striking feature of the temperature stratification is the sharp contrast between the vertical gradients and the relative levels of temperature in the MCS and SCS basins, which results from the difference in mixing and the effect of the Abşeron sill separating the two basins.

Since the density in the Caspian Sea is largely determined by temperature (in the absence of a strong salinity stratification), the temperature contrasts between basins reflect pressure gradients developing as a result of density differences. The largest temperature differences at sill level develop in late winter and early spring when differential mixing and cooling occurs in the two basins. As a result, the dense water in the MCS is expected to flow south across the Abșeron sill to the SCS. The weakness of thermal stratification in the SCS during the following periods appears partly to be a result of the sill overflow and ensuing thermocline-level injections of dense water from the MCS into the SCS. Temperature isolines of colder water on the Abşeron sill area connected to those at the thermocline level of the SCS provide limited evidence in this direction.

A well-developed thermocline generally persists throughout the summer (Fig. 4b), when the mixed layer depth typically decreases to about $15 \mathrm{~m}$. As the stratification develops in either the MCS and the SCS basins the level of the thermocline becomes distinctly different between the basins. While the $11^{\circ} \mathrm{C}$ temperature occurs at about $50 \mathrm{~m}$ depth in MCS in August, it occurs at a depth of about $130 \mathrm{~m}$ in the SCS. (a) 27 August 2004

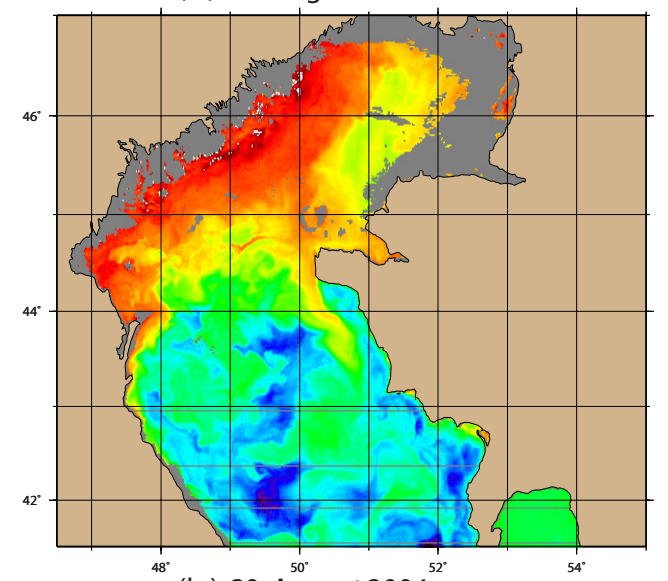

(b) 30 August $2004^{50^{\circ}}$

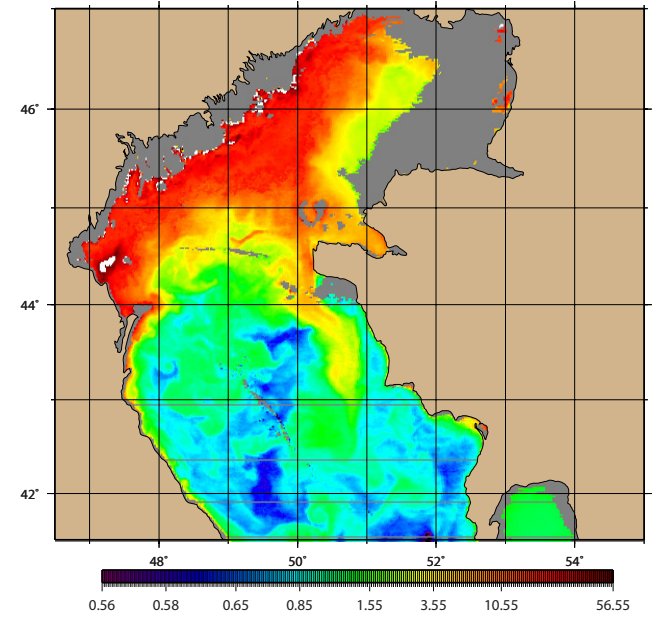

Figure 7. Chlorophyll concentration (in $\mathrm{mg} \mathrm{m}^{-3}$ ) on (a) $27 \mathrm{Au}-$ gust 2004 and (b) 30 August 2004. The chlorophyll concentration contours are plotted with different colours and intervals for a better visualization of the structure.

\section{Mesoscale circulation}

The coastal jets described above and intense circulation cells often become unstable and create eddies and other mesoscale activity responsible for local mixing and transport. A similar role of the rim current is well known in the case of the neighbouring Black Sea (Rachev and Stanev, 1997). The circulation elements also influence preconditioning for wintertime convection contributing to deep/intermediate-water formation.

Model-derived and satellite-detected sea surface temperature (SST), height (SSH) and salinity (SSS) and other fields are often dominated by mesoscale features with patterns that are quite different from the mean circulation patterns discussed in the last section. While the mean fields are dominated by the coastal jets, rim currents and basin-scale gyres, the snapshots are dominated by eddies with horizontal scales 

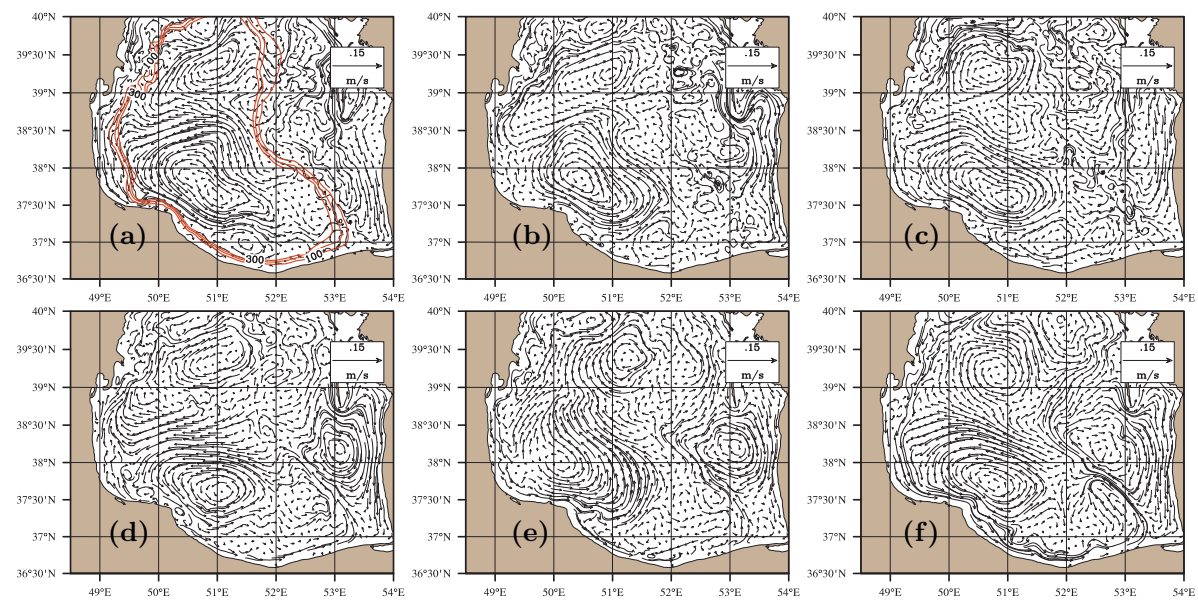

Figure 8. The evolution of the surface flow field in the SCS on 13 July, 12 August and 11 September (upper panels) and 11 October, 10 November and 10 December (lower panels); the red line in the first figure shows the 100, 200 and 300 m bathymetry contour.

of $10-100 \mathrm{~km}$, especially in the upwelling region, along the coastal boundaries and near dense-water formation sites.

Figure 5 shows $0-30 \mathrm{~m}$ average currents in the MCS for the month of July, where a complex pattern of basin circulation is displayed, together with intense southerly coastal jet flows along the western and northeastern coasts. While the flow along the western coast is a relatively steady feature of the circulation, the jet flow near the eastern coast of the MCS which later separates from the coast towards the south is a seasonal feature that starts forming in June and continues to intensify until August. At the headland just north of $43^{\circ} \mathrm{N}$ on the eastern coast, the flow separates from the coast to divide into two branches: while one branch turns to the north and follows the topographic slope between the 100 and $300 \mathrm{~m}$ depth contours, the other branch flows west towards the interior of the sea. This coastal jet advects relatively fresh water of high chlorophyll content from the NCS towards the MCS along the eastern coast. Later, in September, the branch that flows into the interior of the sea increases in intensity. The jet completely disappears in winter, replaced by a northward current joining the basin cyclonic circulation in the same area (see Fig. 3 lower).

Sea surface salinity (SSS) on 28/30/31 July and 1/2/8 August in Fig. 6 shows the coastal jet along the eastern coast of the MCS advecting cold, low-salinity water towards the south. A mushroom like pattern associated with coastal convergence north of the anticyclonic cell on the west coast pumps low-salinity coastal waters towards the interior of the Sea.

Analysis of satellite-derived chlorophyll distribution in Fig. 7 shows southward transport along the western coast of the Caspian Sea in selected cases from August 2004. The development of the southward coastal jet in the northeastern part of the MCS is also evident in the sequence of images in the same figure, in agreement with the seasonal model simulations.
To display mesoscale features in the SCS, we present snapshots of the flow field on 13 July, 12 August, 11 September, 11 October, 10 November and 10 December in Fig. 8. In these figures one can immediately distinguish the basic cyclonic and anticyclonic gyres permanently occupying the south and north of the deep basin, separated by a westward-flowing jet flow, and an anticyclonic circulation in the shallow eastern shelf, all of which are strongly modified with time.

Following the 100-300 m bathymetric contours (drawn in red in Fig. 8a) one can identify basin-wide cyclonic flow in the form of a coastal jet closely following the western and southern coasts. This flow later turns north along the outer edge of the wide eastern shelf, completing a rim-current pattern following the continental slope. The rim current follows topography, which acts like a barrier limiting exchange between coastal/shelf and deep waters and at the same time gives rise to a series of instabilities in the form of mesoscale eddies, wave-like oscillations and filaments. These features in Fig. 8 correspond to a rich field of mesoscale activity.

There are a few modifications over the course of time to the rim current and the embedded simple three-cell circulation of the SCS outlined above. The cyclonic and anticyclonic subbasin gyres display important changes in size and strength, and, as shown in Fig. 8e, the southern cyclonic gyre at times extends to take over part of the anticyclonic circulation to its north and later recedes south. The circulation interacts with the coast and reversals of currents occur in shallow areas landward of the continental slope. Such reversals occur in the northwest coastal sector of the SCS, particularly near the headland around $50.2^{\circ} \mathrm{E}, 37.5^{\circ} \mathrm{N}$, leading to the development of an anticyclonic vortex near $52^{\circ} \mathrm{E}, 37^{\circ} \mathrm{N}$, sheltered from the cyclonic gyre. The flow along the eastern shelf is also highly variable. The intense southerly flow observed in the shallow inner shelf of the southeastern corner in Fig. 8a$\mathrm{c}$ later becomes organized in the form of an anticyclonic gyre 
(a) 19 August 2006

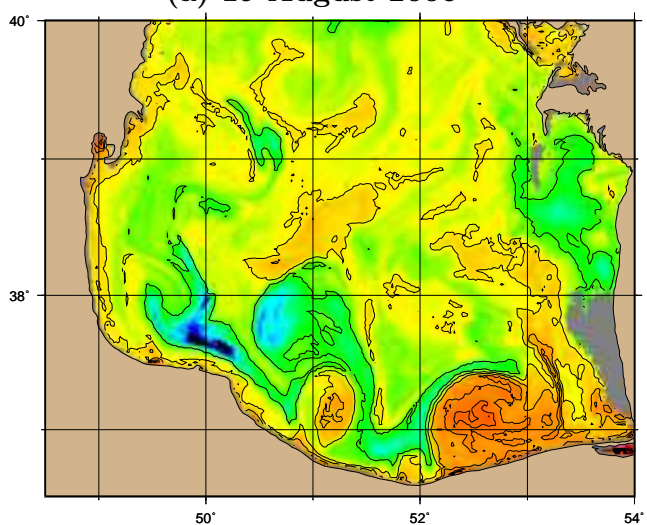

(b) 21 August 2006

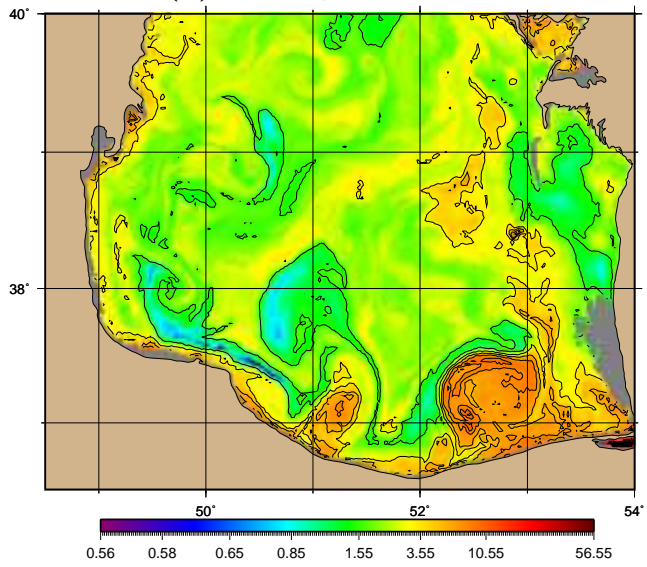

Figure 9. Chlorophyll concentration (in $\mathrm{mg} \mathrm{m}^{-3}$ ) on (a) $19 \mathrm{Au}$ gust 2006 and (b) 21 August 2006. The chlorophyll concentration contours are plotted with different colours and intervals for a better visualization of the structure.

east of the continental slope marked by the 100-300 m depth contours in Fig. 8d-f. The region outside the inner shelf but east of the continental slope displays numerous small eddies and oscillating currents most of the time and especially when the anticyclonic eddy in the southeast is not present.

Some of the features described above are easily detected from satellite data. Chlorophyll concentration obtained from the Moderate-resolution Imaging Spectroradiometer (MODIS)-Aqua satellite sensors in Fig. 9 reveals the rimcurrent structure described above, with a maximum of chlorophyll within the coastal jet outlining the southwestern coast of the SCS and then moving along the continental slope bounding the eastern continental shelf, almost exactly along the 100-300 m contours of bathymetry shown in Fig. 8. The other place where a maximum of chlorophyll concentration is found is along a line extending west from the eastern shelf slope region, which is reminiscent of the jet between the cyclonic and anticyclonic gyres of the western SCS found in our seasonal simulations. High chlorophyll values are found confined to two anticyclonic eddies along the southern coast, similar to the small vortices found there in our simulations.
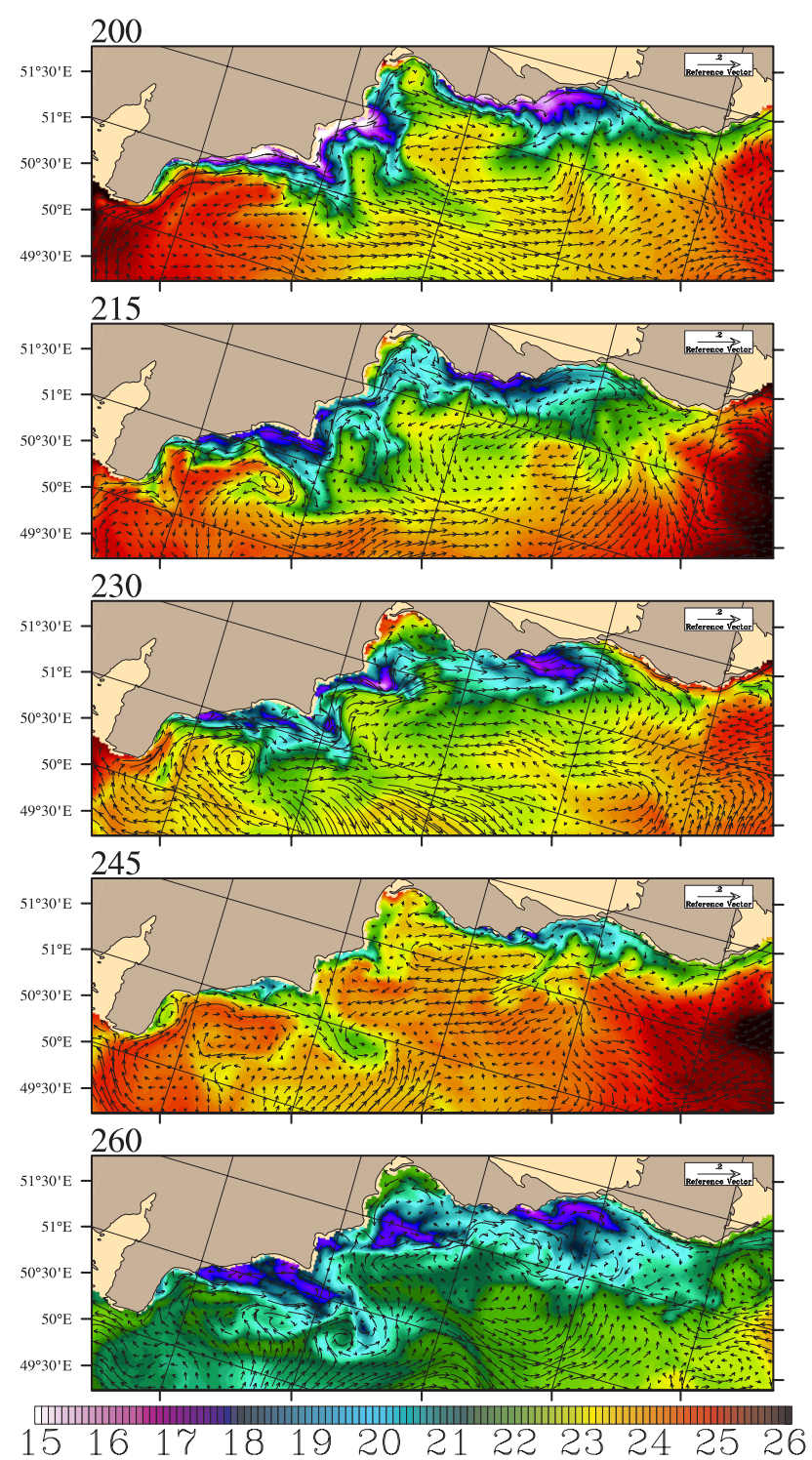

Figure 10. Snapshot of the model SST of the eighth model year along the eastern coast of the Sea. The model days are shown at the upper left side of the each figure.

\section{Upwelling}

In summer through to early fall there is continuous upwelling along the eastern coast of the Caspian Sea, studied by numerous authors (Baidin and Kosarev, 1986; Kosarev, 1975, 1990; Terziev et al., 1992; Sur et al., 2000). Satellite SST data often show relatively colder waters along the coast and filaments penetrating offshore from the upwelling region. The upwelling region extends from $41^{\circ}$ to $44^{\circ} \mathrm{N}$ along the eastern coast with a temperature anomaly of $2-3{ }^{\circ} \mathrm{C}$ in a region extending 5-20 km from the coast. The upwelling at the central part of the eastern coast appears more active in this image, but a review of similar data shows that the upwelling 


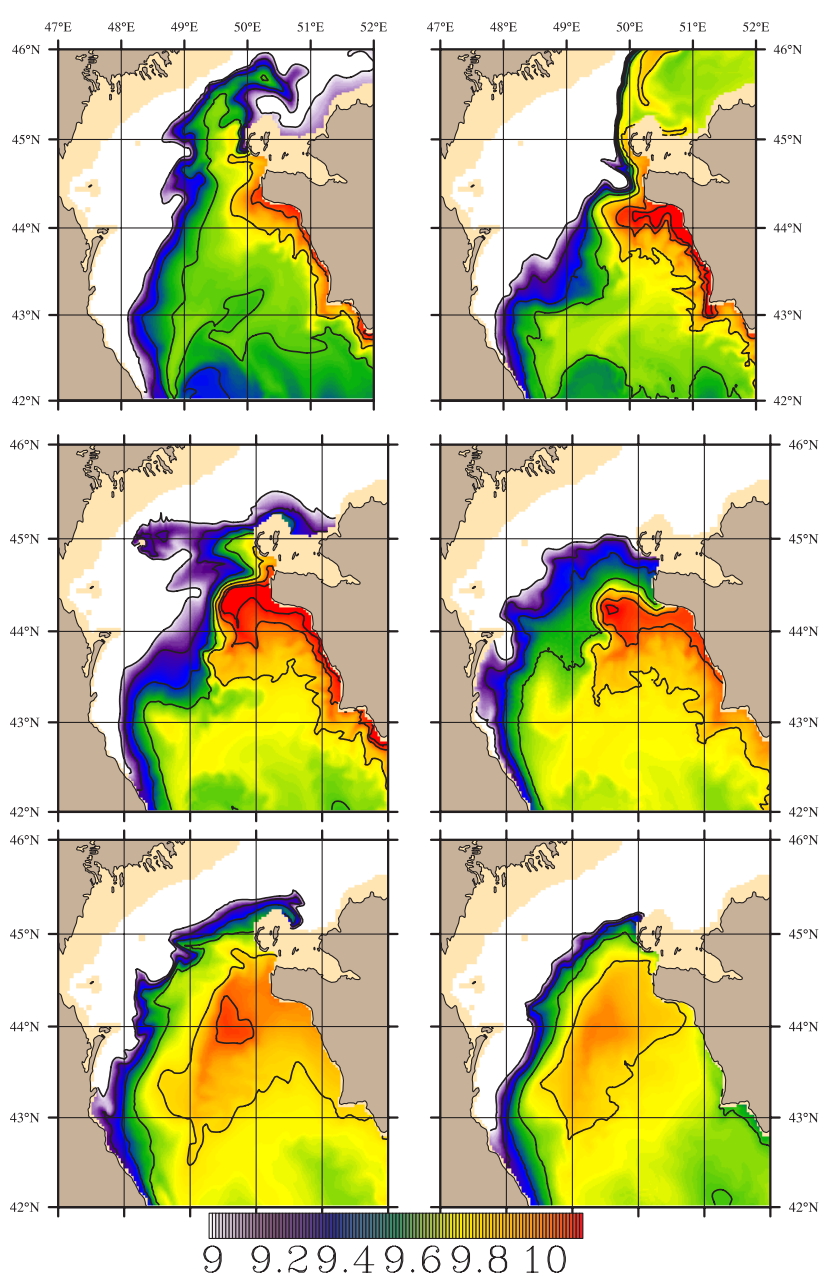

Figure 11. Potential density in sigma-theta units of deepest depth on 2 January and 20 January (upper row), 9 February and 28 February lower (middle row), and 20 March and 1 April (lower row). White areas show a density of less than 9 .

region shifts to the north or south during other times. The eastern coast upwelling is closely related with the predominant northerly winds in summer. The upwelling distribution evidently changes with the wind intensity and direction.

Figure 10 shows snapshots of model SST at days 200, $215,230,245$ and 260 of the model annual cycle at the upwelling region along the eastern coast of the Caspian Sea. Mesoscale dynamic features such as cold filaments and single and mushroom-shaped dipole eddies are often evident in the SST patterns throughout the whole model year. The upwelling at times covers the entire eastern coast, while at other times (e.g. day 245), it almost vanishes. Irregularities along the coast, such as headlands and changes in orientation or slope of the complex topography affect the structure of the upwelled waters. Filaments of upwelled cold water reach the interior of the basin following the generally westward Ekman drift currents at the surface. Upwelling features in the

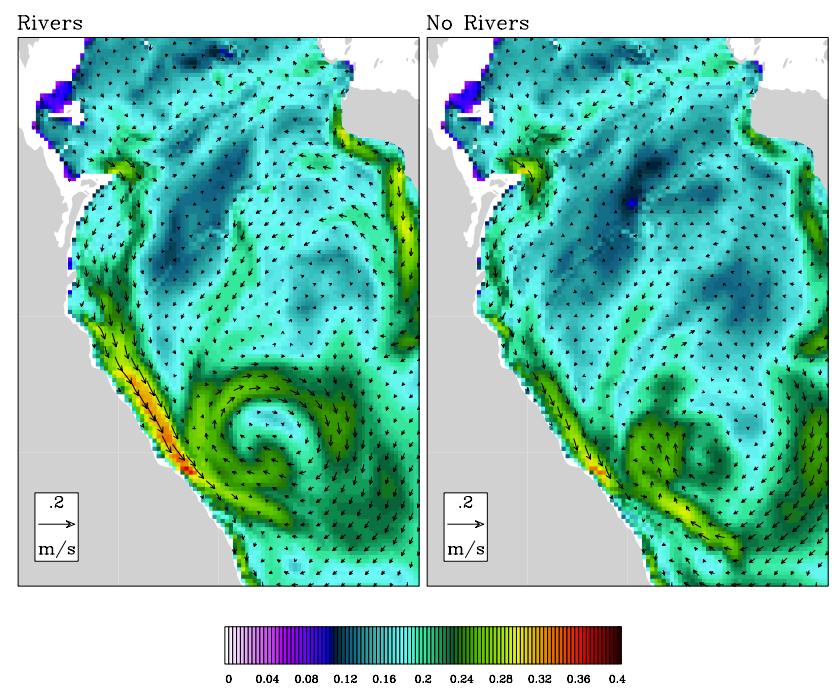

Figure 12. Model surface velocity vector mean and rms vector amplitude over a year's simulation, with rivers and without rivers. Means are denoted with arrows while rms amplitude is colour contoured. Every fourth vector is shown in the along-shore and acrossshore direction.

model-simulated SST are consistent with satellite observations based on the Pathfinder SST data set (not shown).

Compared to the other biologically active upwelling regions of the world ocean, plankton blooms with high chlorophyll concentration are, strangely, not evident in satellite data of the upwelling region along the eastern coast of the Caspian Sea.

An important consequence of Caspian Sea upwelling is the advection of high-salinity water onto the shelf by compensation currents along the coast, creating favourable conditions (preconditioning) for dense-water formation during the later winter period, which then leads to intense slope convection that can ventilate the deeper waters of the Middle Caspian Sea.

\section{Dense-water formation}

Ventilation of the deep waters of the Caspian Sea occurs through a series of complex processes. The rate of formation of dense water is controlled by the rate of cooling in the shallow continental shelf areas in the northern part of the Caspian Sea, ice formation in the North Caspian Sea, saline water ejection by ice, the background stratification and incidence of fronts, fresh-water input, surface fluxes, and mesoscale circulation. The fate of the sinking dense water depends on topography through the latter's influence on the circulation. As dense bottom currents flow down the continental slope and into the sea interior, they entrain lower-density overlying water, thus becoming relatively less negatively buoyant, influencing interior ocean properties (Papadakis et al., 2003). 

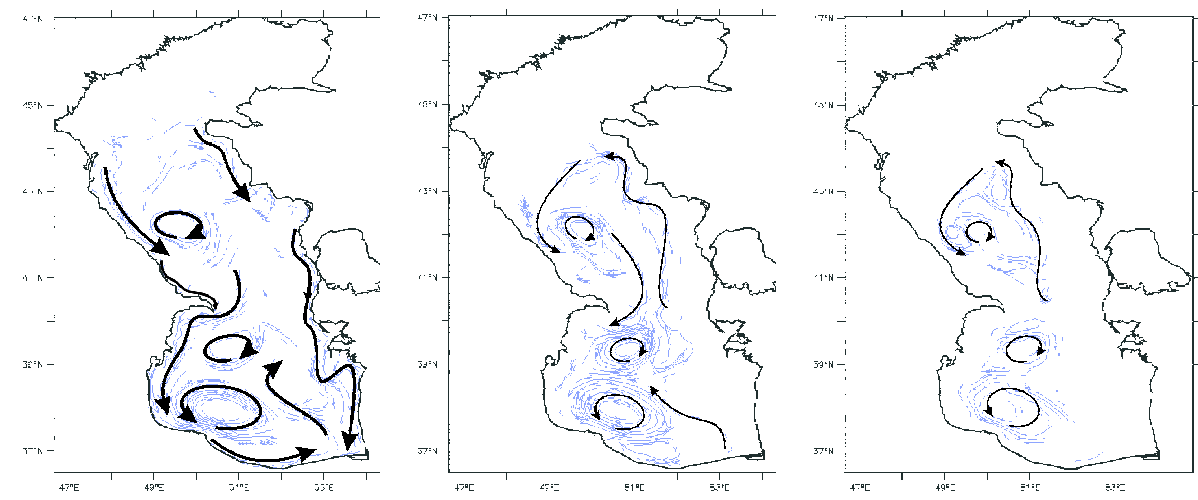

Figure 13. Schematic representation of the annual mean circulation of the Caspian Sea for the depth ranges (left panel) surface (0-10 m), (middle panel) intermediate $(50-100 \mathrm{~m})$ and (right panel) deep $(200-1000 \mathrm{~m})$.

Dense-water formation contributes to renewal of the deep water and thereby affects the circulation of the sea. The mechanism for dense-water formation is not clear in the Caspian Sea. Rodionov (1994) has suggested two possible mechanisms for the sinking of dense water: (1) in summer, evaporation increases the density of sea water at the surface, which then sinks deeper, especially along the eastern coast; (2) in winter, salt ejection by freezing results in saline surface water in the NCS which could be incorporated into the dense water formed. In addition, surface waters flowing northward along the eastern coast of the MCS come into contact with the ice on the northern slopes of the MCS, become denser by cooling and sink to greater depths of the MCS (Ferronsky et al., 2003). Kosarev and Yablonskaya (1994) have also noted that the conditions for the development of wintertime vertical motions are more favourable along the eastern coast compared to other regions.

Based on two cruises undertaken in September 1995 and September 1996 (Peeters et al., 2000) have suggested a similar mechanism for dense-water formation, whereby water transported north along the eastern part of the Caspian Sea becomes colder by encountering the ice and less saline cold water in the north and sinks to the deeper parts of the Middle Caspian Sea. Climatological data show a cold water mass with high density near the eastern coast at $44^{\circ} \mathrm{N}$.

In our model experiments we found dense-water formation in the northeastern part of the MCS as suggested by previous authors. Figure 11 shows the evolution of density of the deepest depth over the dense-water formation site. Beginning with January, day 20, dense water is evident along the eastern coast of the sea, mostly confined along the eastern coast of the sea. The density of waters along the eastern coast gradually increases in February and begins to move to the interior of the sea. In March dense water flows down at the continental slope and fills the interior of the sea. Beginning in April the density of deepest depth become similar to the density of the surrounding waters, and dense-water generation is completed along the eastern coast.

\section{Role of the rivers}

With fresh-water inputs from a large river such as the Volga, the river buoyancy contribution is commonly expected to be an important driver of circulation. In the case of the Caspian Sea, the observed southward flow along the western coast is anticipated to be a major component of this buoyancydriven circulation. To test this statement, an experiment was designed in which the river runoff is turned off, leaving climatological surface fluxes and wind stress as the only forcing.

Turning rivers off, it is found that main features of the circulation are preserved, though weaker. It is also noteworthy that not only the surface currents, but also the deeper currents decrease in intensity when the rivers are turned off. Figure 12 compares the annual mean surface currents in the MCS with and without rivers in better detail. There is significant weakening of the west coast southerly jet and the Derbent anticyclone fed by this current when the river inflow is turned off. The other feature noted in Fig. 12 is the decrease in intensity of the current near the northeastern coast of the basin. The similarity of the other features with and without the river effect illustrates the roles of the wind and surface buoyancy forcing in maintaining these circulation features. The freshwater discharge appears primarily responsible for maintaining the pronounced southward-flowing coastal jet and the anticyclone along the west coast, as well as the surface coastal jet on the eastern coast of the MCS. The effect of major rivers in the north is of consequence in the SCS: the cyclonic gyre in the northwest of the SCS becomes much weaker, while the cyclonic gyre in the southeast becomes more intense and covers almost the entire basin in the case without river runoff.

\section{Conclusions}

A high resolution eddy-resolving hydrodynamic model was used to investigate the dynamics of the Caspian Sea circulation. The model, forced by climatological mean seasonal 
atmospheric forcing and river inputs of fresh water, successfully reproduces the rather well-known features of the Caspian Sea circulation and reveals the mesoscale variability of the circulation.

Based on the model results, the circulation at the surface, at intermediate depth below the mixed layer and at deeper levels is schematized in Fig. 13 based on the annual circulation patterns presented in Fig. 3. These schematic patterns were constructed by eliminating currents of magnitude greater than $2.5 \mathrm{~cm} \mathrm{~s}^{-1}$ at the surface, $1 \mathrm{~cm} \mathrm{~s}^{-1}$ at intermediate depth and $0.3 \mathrm{~cm} \mathrm{~s}^{-1}$ at the deep level and by using the remaining current vectors.

The surface circulation (Fig. 13, left panel) consists of narrow coastal jets originating in the north and flowing south along western and eastern coasts. Part of the flow escaping from these jets near headlands is incorporated into other elements of the circulation. In this way, the coastal jets and the anticylonic/cyclonic gyres in the individual basins are interconnected by thin streams of currents which follow the coast and the continental slope. In a number of cases, a strong current following a stream is diverted by a nearby feature, running in the opposite direction to its first orientation: for example, at the headland on the northeastern coast, along the western coast in the proximity of the anticyclonic gyre of the MCS, at the southern coast and on the eastern side of the dipole in the SCS.

The intermediate depth circulation, Fig. 13, middle panel, is much simpler, and consists of the anticyclone in the MCS, the cyclone/anticyclone pair in the SCS and a south to north current along the main eastern basin topographic slope (which extends to the mid-basin in the SCS and appears closer to the eastern coast in the MCS). This northward current then interconnects to the cyclonic/anticyclonic cells on the western side of the basin.

The deep circulation, Fig. 13, right panel, consists only of the anticyclonic cell in the MCS and the cyclonic/anticyclonic pair in the SCS, without appreciable slope currents joining them. Overall, the three major cells of circulation and shelf currents displayed in Fig. 13 appear to have significant barotropic components.

Acknowledgements. We would like to thank R. Ibrayev for numerous discussions and data support. The numerical HYCOM simulations were performed under the National Center for High Performance Computing (NCHPC) at the Istanbul Technical University, Istanbul Turkey. This research is funded by Multidisciplinary Analysis of the Caspian Sea Ecosystem (MACE) project.

Edited by: E. J. M. Delhez

\section{References}

Arpe, K. and Roeckner, E.: Simulation of the hydrological cycle over Europe: Model validation and impacts of increasing greenhouse gases, Adv. Water Resour., 23, 105-119, 1999.
Arpe, K., Bengtsson, L., Golitsyn, G. S., Mokhov, I. I., Semenov, V. A., and Sporyshev, P. V.: Connection between Caspian sea level variability and ENSO, Geophys. Res. Lett., 27, 2693-2696, 2000.

Baidin, S. S. and Kosarev, A. N. (Eds.): The Caspian Sea, Hydrology and Hydrochemistry, Nauka, 1986.

Beletsky, D. and Schwab, D. J.: Modeling circulation and thermal structure in Lake Michigan: Annual cycle and interannual variability, J. Geophys. Res.-Oceans, 106, 19745-19771, 2001.

Bengtsson, L.: Climate modelling and prediction, Achievements and challenges, in: WMO/IOC/ICSU Conference On The WCRP Climate Variability And Predictability Study (CLIVAR), UNESCO, Paris, 1998.

Bleck, R.: An oceanic general circulation model framed in hybrid isopycnic-Cartesian coordinates, Ocean Model., 4, 55-88, 2002.

Bleck, R.: On the use of hybrid vertical coordinates in ocean circulation modeling, in: Ocean Weather Forecasting: An Integrated View of Oceanography, edited by: Chassignet, E. and Verron, J., pp. 109-126, international Summer School of Oceanography, Agelonde in Lalonde-Les Maures, Agelonde, FRANCE, 20 September-1 October 2004, 2006.

Bondarenko, A. L. (Ed.): Currents of the Caspian Sea and Formation of Salinity of the Waters of the North Part of the Caspian Sea, Nauka, Moscow, 1993.

Chassignet, E., Smith, L., Halliwell, G., and Bleck, R.: North Atlantic Simulations with the Hybrid Coordinate Ocean Model (HYCOM): Impact of the vertical coordinate choice, reference pressure, and thermobaricity, J. Phys. Oceanogr., 33, 2504-2526, 2003.

Chen, C., Zheng, L., and Blanton, J.: Physical processes controlling the formation, evolution, and perturbation of the low-salinity front in the inner shelf off the southeastern United States: A modeling study, J. Geophys. Res.-Oceans, 104, 1259-1288, 1999.

Dumont, H.: The Caspian Lake: History, biota, structure, and function, Limnol. Oceanogr., 43, 44-52, 1998.

Ferronsky, V., Brezgunov, V., Vlasova, L., Polyakov, V., Froehlich, K., and Rozansky, K.: Investigation of Water-Exchange Processes in the Caspian Sea on the Basis of Isotopic and Oceanographic Data, Water Resour., 30, 10-22, 2003.

Gunduz, M.: Caspian Sea surface circulation variability inferred from satellite altimeter and sea surface temperature, J. Geophys. Res.-Oceans, 119, 1420-1430, 2014.

Ibrayev, R., Sarkisyan, A., and Trukhchev, D.: Seasonal variability of the circulation of the Caspian Sea reconstructed from mean multi-year hydrological data, Izvestiya, Atmos. Ocean. Phys., 37, 103-111, 2001.

Ibrayev, R. A., Özsoy, E., Schrum, C., and Sur, H. İ.: Seasonal variability of the Caspian Sea three-dimensional circulation, sea level and air-sea interaction, Ocean Sci., 6, 311-329, doi:10.5194/os6-311-2010, 2010.

Kara, A., Hurlburt, H., Wallcraft, A., and Bourassa, M.: Black sea mixed layer sensitivity to various wind and thermal forcing products on climatological time scales, J. Climate, 18, 5266-5293, 2005.

Kelly, K. A., Thompson, L., Cheng, W., and Metzger, E. J.: Evaluation of HYCOM in the Kuroshio Extension region using new metrics, J. Geophys. Res.-Oceans, 112, doi:10.1029/2006JC003614, 2007. 
Klevtsova, N. (Ed.): Sea current regime near east coast of the middle and south Caspian basin., Vol. 3, Proceeding of Hydro-meteo observatory of Baku, 1967.

Knysh, V., Ibrayev, R., Korotaev, G., and Inyushina, N.: Seasonal variability of climatic currents in the Caspian Sea reconstructed by assimilation of climatic temperature and salinity into the model of water circulation, Izvestiya, Atmos. Ocean. Phys., 44, 236-249, 2008.

Kosarev, A. (Ed.): Hydrology of the Caspian and Aral Seas, Mosk Gos Univ, Moscow, 1975.

Kosarev, A. (Ed.): The Caspian Sea, Water structure and dynamics, Nauka, Moscow, 1990.

Kosarev, A. and Yablonskaya, E.: The Caspian Sea, SPB Academic Publishing, The Hague, 1994.

Kourafalou, V., Oey, L., Wang, J., and Lee, T.: The fate of river discharge on the continental shelf .1. Modeling the river plume and the inner shelf coastal current, J. Geophys. Res.-Oceans, 101, 3415-3434, 1996.

Lazure, P. and Jegou, A.-M.: 3D modelling of seasonal evolution of Loire and Gironde plumes on Biscay Bay continental shelf, Oceanol. Acta, 21, 165-177, 1998.

Lednev, V. A. (Ed.): Currents of the Northern and Central Parts of the Caspian Sea, Moscow, 1943.

Özsoy, E.: Sensitivity to Global Change in Temperate Euro-Asian Seas (The Mediterranean, Black Sea and Caspian Sea): A Review, in: The Eastern Mediterranean as a Laboratory Basin for the Assessment of Contrasting Ecosystems, edited by: Malanotte-Rizzoli, P. and Eremeev, V., Vol. 51 of NATO Science Series, 281-300, Springer Netherlands, 1999.

Özsoy, E., Kubilay, N., Nickovic, S., and Moulin, C.: A hemispheric dust storm affecting the Atlantic and Mediterranean in April 1994: Analyses, modeling, ground-based measurements and satellite observations, J. Geophys. Res.-Atmos., 106, 1843918460, 2001.

Papadakis, M., Chassignet, E., and Hallberg, R.: Numerical simulations of the Mediterranean sea outflow: impact of the entrainment parameterization in an isopycnic coordinate ocean model, Ocean Model., 5, 325-356, 2003.

Peeters, F., Kipfer, R., Achermann, D., Hofer, M., AeschbachHertig, W., Beyerle, U., Imboden, D., Rozanski, K., and Frohlich, K.: Analysis of deep-water exchange in the Caspian Sea based on environmental tracers, Deep-Sea Res. Pt. I, 47, 621-654, 2000.
Pettenuzzo, D., Large, W., and Pinardi, N.: On the corrections of ERA-40 surface flux products consistent with the Mediterranean heat and water budgets and the connection between basin surface total heat flux and NAO, J. Geophys. Res.-Oceans, 115, C06022, doi:10.1029/2009JC005631, 2010.

Rachev, N. H. and Stanev, E. V.: Eddy Processes in Semienclosed Seas: A Case Study for the Black Sea, J. Phys. Oceanogr., 27, 1581-1601, 1997.

Rodionov, S.: Global and regional climate interaction: The Caspian Sea experience, Kluer Academic Publ., Dordrecht, The Netherlands, 1994.

Sarkisyan, A. S., Zaripov, B. R., Kosarev, A. N., and Rzheplinski, D. G.: Diagnostic calculations of currents in the Caspian Sea., Izvestiya, Atmos. Ocean. Phys., 12, 1106-1110, 1976.

Stockman, W.: Investigation of current kinematics at the western shore of the central part of the Caspian Sea, Vol. 1, Transactions of the Azerbaidjan Scientific-Investigative Fishery station, 1938.

Sur, H. I., Özsoy, E., and Ibrayev, R.: Chapter 16 Satellitederived flow characteristics of the Caspian Sea, in: Satellites, oceanograghy and society, edited by: Halpern, D., Vol. 63 of Elsevier Oceanography Series, 289-297, Elsevier, 2000.

Terziev, F., Kosarev, A., and Keromov, A. (Eds.): Hydrometeorology and hydrochemistry of Seas, Vol. VI, The Caspian Sea, Gidrometeoizdat, Leningrad, 1992.

Trukhchev, D., Kosarev, A., Ivanova, D., and Tuzhilkin, V.: Numerical Analysis of the general circulation in the Caspian Sea, Comptes Rendus de l'Academie Bulgare des Sciences, 35-38, 1995.

Tsytsarev, A. N. (Ed.): Peculiarities of drift currents near Kura river mouth, 5, Proceeding of Baku Hydrometeobservatory, 1967.

Tuzhilkin, V., Kosarev, A. N., Trukhchev, D. I., and Ivanov, V. P.: Seasonal features of General Circulation in the Caspian Deepwater, Meterorol. Hydrol., 1, 91-99, 1997.

Vorosmarty, C., Sharma, K., Fekete, B., Copeland, A., Holden, J., Marble, J., and Lough, J.: The Storage and Aging of Continental Runoff in Large Reservoir Systems of the World, Ambio, 26, 210-219, 1997.

Wallcraft, A., Kara, A., Hurlburt, H., and Rochford, P.: The NRL Layered Global Ocean Model (NLOM) with an embedded mixed layer submodel: Formulation and tuning, J. Atmos. Ocean. Tech., 20, 1601-1615, 2003. 